See discussions, stats, and author profiles for this publication at: https://www.researchgate.net/publication/315338050

\title{
Identity Politics in Indonesia
}

Working Paper $\cdot$ March 2017

DOI: 10.13140/RG.2.2.16590.66887

\section{1 author:}

8 PUBLICATIONS 2 CITATIONS

SEE PROFILE 


\title{
ANALISIS POLITIK IDENTITAS DI INDONESIA
}

\author{
Muhammad Habibi
}

Fakultas Ilmu Sosial dan Ilmu Politik, Universitas Mulawarman, Samarinda

E-mail: habibi.id@gmail.com

\begin{abstract}
Abstrak: Indonesia adalah negara kepulauan yang terluas di muka bumi. Jumlah pulaunya lebih dari 17.000, etnisitas, sub-kultur, dan bahasa lokalnya ratusan. Bahkan di Papua saja misalnya, tidak kurang dari 252 suku dengan bahasa khasnya masing-masing. Dari sisi keragaman budaya (pluralisme) ini saja, jika Indonesia bisa bertahan dalam tempo lama, maka menurut saya adalah mukjizat sejarah yang bernilai sangat tinggi. Oleh sebab itu, apa yang bernama politik identitas yang sering muncul ke permukaan sejarah modern Indonesia harus ditangani dan dikawal secara bijak oleh nalar historis yang dipahami secara benar dan cerdas. Saat proklamasi, jumlah penduduk Indonesia adalah sekitar 70 juta; sekarang di awal abad ke-21 sudah menjadi sekitar 250 juta, mem bengkak lebih tiga kali lipat sejak 1945, telah muncul sebagai bangsa terbesar keempat di dunia sesudah Cina, India, dan Amerika Serikat.Dengan masyarakat yang terdiri dari beranekaragam etnis, agama, dan budaya yang berbeda, masyarakat Indonesia dapat saling menghargai dan toleransi antar perbedaan yang ada. Oleh karena itu perlu menganalisis terjadinya politik identitas di Indonesia
\end{abstract}

Kata kunci: Politik Identitas, Multikultural, Politik Etnis, Politik Agama

\section{Konsep, Gagasan, \\ Perkembangan, Kelebihan dan Kelemahan Politik Identitas}

Sebagai suatu konsep yang
sangat mendasar, apa yang
dinamakan identitas tentunya
menjadi sesuatu yang sering kita
dengar. Terlebih lagi, ini merupakan
konsep yang menjadi basis untuk
pengenalan sesuatu hal. Kita akan
mengenali sesuatu halnya itu kalau
kita tahu identitasnya. Ini juga akan
berarti bahwa kalau kita mengenali
identitas sesuatu hal, maka kita akan

memiliki pengetahuan akan sesuatu halnya itu. Politik identitas adalah nama lain dari biopolitik dan politik perbedaan. Biopolitik mendasarkan diri pada perbedaan-perbedaan yang timbul dari perbedaan tubuh. Identitas menurut Jeffrey Week adalah berkaitan dengan belonging tentang persamaan dengan sejumlah orang dan apa yang membedakan seseorang dengan yang lain. Pendapat Jeffrey Week tersebut menekankan pentingnya identitas bagi tiap individu maupun bagi suatu 
kelompok atau komunitas

(Widayanti, 2009: 14).

Menyebarnya politik identitas atau biopolitik dalam pandangan Foucault merupakan akibat dari runtuhnya "masyarakat yang direncanakan secara ilmiah" yang merupakan suatu gerakan dengan implementasi kontrol demografis objektif. Inilah dasar-dasar biopolitik. Seorang Foucault merasa diasingkan, disendirikan, dengan cara dibaptis yang memaksanya menyandang suatu identitas baru sebagai seorang Kristen. Politik identitas merupakan kekhasan yang terjadi pada negara dan masyarakat modern (liberal dan demokratis), sebagaimana penyelidikan Foucault, untuk menerapkan prinsip-prinsip ilmiah terhadap tubuh individual dalam proses politik melalui kekuasaan negara. Tujuanyan adalah agar orang "tercerahkan": mencapai pertumbuhan populasi optimum, pertumbuhan generasi yang proporsional, dan lain-lain. Dalam hai ini, tolak ukurnya adalah standar negara, tidak pernah berdasarkan individu atau masyarakat. Bagi Foucault, hasilnya ternyata mencenagkan karena sikap ilmiah dan cakupannya kesegala aspek sehingga menjadi bentuk kontrol dan tirani absolut. Dengan demikian, tubuh terlempar kedalam penjara jiwa. Abdillah (2002:61)

\section{A. Konsep Politik Identitas}

Politik identitas sendiri merupakan konsep baru dalam kajian ilmu politik. Politik identitas adalah nama lain dari biopolitik dan politik perbedaan. Biopolitik mendasarkan diri pada perbedaan-perbedaan yang timbul dari perbedaan tubuh. Dalam filsafat, sebenarnya wacan ini sudah lama muncul, namun penerapannya dalam kajian ilmu politik mengemuka setelah disimposiumkan pada suatu pertemuan internasional Asosiasi Ilmuan Politik Internasional di Wina pada $1994{ }^{1}$

\section{Pertemuan}

tersebut

menghasilkan konsepsi tentang dasar-dasar praktek politik identitas

\footnotetext{
${ }^{1}$ Simposium ini diadakan oleh European Centre for Social Welfare Policy dan Dr. Karl Renner Institute, serta disponsori oleh Jewish Museum of Vienna, dan Department of Scientifict Affairs. Hasil simposium tersebut dibukukan dalam bentuk antologi yang dieditori oleh Agnes Heller dan Sonja Puntscher Riekmann dengan judul Biopolitics: The Politics of The Body, Race and Nature, (Brookfield:Avebury, 1996).
} 
dan menjadikannya sebagai kajian dalam bidang ilmu politik. Agnes Haller mengambil definisi politik identitas sebagai konsep dan gerakan politik yang fokus perhatiannya adalah perbedaan (difference) sebagai suatu kategori politik yang utama. Setelah kegagalan narasi besar (grand narative), ide perbedaan telah menjanjikan suatu kebebasan (freedom), toleransi dan kebebasaan bermain (free play), meskipun kemudian ancaman baru muncul. Politik perbedaan menjadi suatu nama baru dari politik identitas; rasisme (race thinking), biofeminimisme dan perselisihan etnis menduduki tempat yang terlarang oleh gagasan besar lama. Berbagai bentuk baru intoleransi, praktek-praktek kekerasan pun muncul. Heller (1995: ix).

\section{B. Gagasan Politik Identitas}

Dalam situasi keterserakan identitas dan entitas-entitas perbedaan, politik perbedaan dan entitas-entitas perbedaan, politik perbedaan sangat subur dalam situasi negara atau masyarakat yang multikultural dan multietnis. Dalam kerangka ini, hubungan interaktif antar kelompok perbedaan, terutama kelompok etnis yang berbeda-beda harus menjalin suatu kerangka etis, dalam hal ini adalah sikap toleran. Toleransi politik hanya mungkin dalam suasana politik negara yang demokratis. Oleh karena toleransi politik (political tolerance) sangat dipengaruhi oleh sistem, struktur, dan atmosfer politik yang berlaku. John Sullivan at al. yang menganalisis konsep dan penerapan toleransi poltik di tiga negara yang berbeda: Amerika Serikat,Selandia Baru, dan Israel, menemukan kadar intensitas toleransi yang berbedabeda. Hal tersebut dipengaruhi oleh faktor-faktor antara lain tingkat kemakmuran ekonomi, struktur dan sistem politik, faktor psikologi politik.

Konsep politik identitas relevan untuk diterapkan, paling tidak diwacanakan mengingat peta politik masa depan, yang berkembang ke arah politik yang beragam, lebih melihat kembali pada tataran humanitas dan etik. Geoff Mulgan seorang ilmuwan politik, mengemukakan bahwa peran-perang 
etis dan moral harus dikedepankan.

Oleh karena seiring runtuhnya narasi besar, ideologi-ideologi besar, partaipartai politik berkurang perannya. Moralitas pun akan lebih dibutuhkan untuk mengatasi gejolak-gejolak politik dan menumbuhkan perilaku politik yang etis dan bermoral. Sejalan dengan Mulgan, Walter Lippmann (1950) dalam filsafat publiknya mendorong para politikus demokrasi untuk menjunjung tinggi moralitas berpolitik. Hal ini dikarenakan dalam negara-negara demokratis sekalipun penyakit dari terbukanya kebebasan akan senantiasa muncul, sehingga perlu adanya suatu tatanan etika dan moralitas demokrasi. Robert Hafner (2007).

\section{Perkembangan Politik Identitas}

Klaus Von Beyme menganalisis karakter gerakan identitas dalam beberapa tahap perkembangannya, mulai dari tahap pramodern sampai dengan postmodern. Perpecahan fundamental, kelompok-kelompok kesukuan dan kebangsaan memunculkan gerkan sosial politik yang menyeluruh. Dalam hal ini mobilisasi secara ideologis diprakarsai oleh para pemimpin. Tujuannya adalah perampasan dan perebutan kekuasaan dari suatu penguasa ke penguasa yang baru.

Pada tahap modern, gerakan tersebut muncul dengan adanya pendekatan kondisional, keterpecahan membutuhkan sumbersumber untuk dimobolisasi. Terjadi keseimbangan mobilisasi dari atas dan partisipasi dari bawah, peran pemimpin tidak lagi dominan dan tujuan akhirnya adalah pembagian kekuasaan.

Kemudian pada perkembangan pos modern, munculnya gerakan-gerakan itu berasal dari dinamikanya sendiri, protes muncul atas berbagai macam kesempatan individual, tidak ada satu kelompok atau pecahan yang dominan. Pola aksi dan kegiatannya berdasarkan kesadaran diri yang bersifat otonami sebagai tujuan finalnya. Bayme, (1996: 122). Hasil dari analisis Von Beyme digambarkan melalui tabel berikut: 
Tabel 1.1 Tahap Perkembangannya Politik Identitas

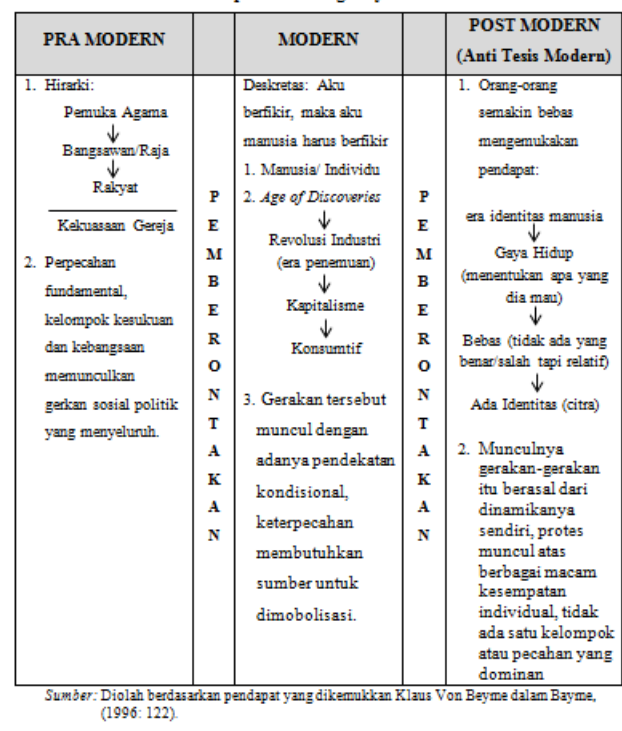

Kemunculan politik etnis diawali dengan tumbuhnya kesadaran yang mengidentikan mereka kedalam suatu golongan atau kelompok etnis tertentu. Kesadaran ini kemudian memunculkan solidaritas kekelomokkan dan kebangsaan. Politik etnis mengacu pada politik "kelompok etnis" dan "minoritas kecil", sementara penfsiran kelomok etnis bisa mencakup bangsa etnis (ethnic nation). Pada wacana politik kontemporer nuansanya lebih sempit. Dalam konteks ini, biasanya kelompok etnis atau minoritas etnis tidak memiliki teritori tertentu. Tujuan mereka pun berbeda dengan nasionalis klasik, mereka tidak menghendaki "determinasi diri kebangsaan" dalam suatu wilayah bangsa (negara). Akan tetapi, lebih pada penerimaan proteksi dan kemajuan bagi kelompok, khususnya bagi individu-individu dalam kelompok itu, dalam suatu negara yang telah ada. Kellas, (1988:119).

\section{Kelebihan dan Kelemahan Politik Identitas}

Pemaknaan politik identitas antara Kemala dengan Agnes Heller dan Donald L Morowitz sangat berbeda. Kemala melangkah lebih jauh dalam melihat politik identitas yang terjadi pada tataran praktis. Yang biasanya digunakan sebagai alat memanipuiasi alat untuk menggalang politik guna kepentingan ekonomi dan politik. Namun pada bagian yang lain, argumen Kemala mengalami kemunduran penafsiran dengan mengatakan bahwa: Dalam politik identitas tentusaja ikatan kesukuan mendapat Peranan penting, ia menjadi simbol-simbol budaya yang potensial serta menjadi surnber kekuatan untuk aksi-aksi politik. 
Pemahaman ini berimplikasi pada kecenderungan untuk: Pertama, ingin mendapat pengakuan dan perlakuan yang setara atau dasar hakhak sebagai manusia baik politik, ekonomi maupun sosial-budaya. Kedua, demi rnenjaga dan melestarikan nilai budaya yang menjadi ciri khas kelompok yang bersangkutan. Terakhir, kesetiaan yang kuat terhadap etnisitas yang dimilikinya.

Gerakan politik identitas pada dasarnya membangun kembali "narasi besar"' yang prinsipnya mereka tolak dan membangun suatu teori yang mengendalikan faktorfaktor biologis sebagai penyusun perbedaan-perbedaan mendasar sebagai realitas kehiduparmya; Dalam gerakan politik identitas ada suatu tendensi untuk membangun sistem apartheid terbalik. Ketika kekuasaan tidak dapat ditaklukkan dan pembagian kekuasaan tidak tercapai sebagai tujuan gerakan, pemisahan dan pengecualian diri diambil sebagai jalan keluar; Kelemahan dari gerakan politik identitas adalah upaya untuk menciptakan kelompok khusus.
Sebagai contoh, dalam kontestasi pilkada DKI terjadi sentimen politik identitas yang sangat kuat, dimana pribumi mengkhususkan diri dan menolak non-pribumi, hal ini terkait dengan ketika kekuasaan tidak dapat ditaklukkan dan pembagian kekuasaan tidak tercapai sebagai tujuan gerakan, pemisahan dan pengecualian diri diambil sebagai jalan keluar untuk menjatuhkan pasangan calon yang lain.

Sedangkan hal positif yang dapat diambil dari politik identitas adalah ada upaya untuk tetap melestarikan nilai budaya yang menjadi ciri khas kelompok yang bersangkutan, sehingga pengguatan akan budaya tidak akan luntur dan hilang. Penguatan identitas tersebut muncul apabila identitas yang dikonsepkan untuk mewadahiya dirasa tidak dapat mewakili atau menyatukan kelompok-kelompok tersebut. Bahkan, kekuatan kolompok tersebut menimbulkan juga ketegangan antar kelompok untuk memperoleh dominasi dari sebuah konsep yang akan dibangun. Penguatan identitas kelompok untuk menjadikannya sebagai dominasi 
dalam sebuah wadah atau bahkan keluar dari wadah disebut sebagai Politik Identitas. Tujuan sebenarnya dari politik adalah mencapai kebaikan bersama. Maka menurut kami bagaimana pun caranya, entah dengan menggunakan politik identitas atau identitas politik, asalkan pemerintahan yang dibangun atas dasar politik tersebut mampu mewujudkan kebaikan bersama maka ia menjadi baik.

\section{Sejarah Perkembangan Politik} Agama di Indonesia, Kelebihan dan Kekurangan dari

\section{Perkembangan Politik Agama}

A. Sejarah Perkembangan Politik Agama di Indonesia

Sejarah mencatat, tokoh, komunitas, dan institusi keagamaan bisa berperan menjadi penjaga moral masyarakat serta pengkritik kekuasaan yang garang. Pula, agama bisa menjadi sumber energi luar biasa untuk melakukan perlawanan terhadap rezim korup dan despotik. Sejarah gerakan Gereja Katolik di Amerika Latin, Black Chruches di Amerika Serikat, Sufi Sanusiyah di Lybia, atau Tarekat Qadiriyah-
Naqsabandiyah di Banten, Indonesia, hanyalah sekelumit contoh sejarah dimana agama telah melakukan fungsi kritisnya sebagai medium kritik sosial sebuah masyarakat sekaligus sarana perubahan politik sebuah tatanan kekuasaan.

Penting untuk dicatat, bukan hanya agama yang melakukan perlawanan terhadap politik. Politik juga sering melawan, mengintimidasi, dan menghancurkan agama. Dengan kata lain, hubungan sekaligus nasib agama dan politik akan ditentukan oleh otoritas mana yang paling kuat dan dominan dari keduanya serta bagaimana watak dan karakter para elit politik dan elit agama yang kebetulan berkuasa. Jika politik menjadi "superordinat", maka agama akan berpotensi menjadi "subordinat". Begitu pula sebaliknya. 2

Politik agama dalam konteks sejarah Indonesia, terjadi perkembangan yang terus berubah dan berkembang menyangkut relasi agama dan politik dapat dibagi

\footnotetext{
2 Sumanto Al Qurtuby. 2016. Agama, Politik, dan Politik Agama. http://www.dw.com. diakses pada 11 Maret 2016
} 
menjadi 4 zaman yaitu Kolonial, Orde Lama, Orde Baru, dan Era Revormasi. Pada masa Kolonial, agama berperan ganda: sebagai legitimasi kolonialisme sekaligus kritik sosial. Banyak tokoh agama, yang bekerja dengan pemerintah kolonial. Tetapi pada saat yang bersamaan juga banyak di antara mereka yang menjadi pengkritik dan pemberontak kolonial. Misal Kiai Mahfudh (1901-1950) yang aktif berjuang di medan pertempuran dan memiliki strategi jitu dalam mengorganisasi pasukan. Ia membentuk laskar santri, dalam barisan Angkatan Oemat Islam (AOI) dalam melawan penjajah. ${ }^{3}$

Pada zaman Orde Lama, Presiden Sukarno di satu sisi mengakomodasi tokoh-tokoh Muslim Nahdlatul Ulama, Muhammadiyah,

\footnotetext{
${ }^{3}$ AOI terbentuk pada 27 Ramadhan 1346 H/ 4 September 1945. Pada waktu itu, tentara nasional sebagai pasukan militer Negara Indonesia belum sepenuhnya solid. Masa awal kemerdekaan, masih dalam transisi kepemimpinan, ekonomi dan konsolidasi pasukan militer. Pasukan-pasukan militer yang terdiri dari berbagai latar belakang ideologi, golongan dan etnis, masih tercerai berai. Pasukan yang dikomando Panglima Soedirman juga masih menata barisan. Hal ini, sebagaimana tercatat dalam thesis Atik Maskanatun Ni'amah (2013), "Biografi Syaikh Mahfudh al-Hasani Somalangu Kebumen (1901-1950)".
}

Masyumi bahkan dari organisasi tersebut betul-betul terjun kedalam politik praktis yaitu dengan mendirikan partai politik, muskipun pada akhirnya Soekarno menerbitkan Keppres Nomor 200/1960 tanggal 15 Agustus 1960, yang isinya membubarkan Masyumi dan Partai Sosialis Indonesia (PSI). Namun pelaksanaan pembubaran itu harus dilakukan sendiri oleh Masyumi dan PSI. Jika dalam tempoh seratus hari kedua partai itu tidak membubarkan diri, maka partai itu akan dinyatakan sebagai partai terlarang. Sebab itulah Ketua Umum Masyumi Prawoto Mangkusasmito dan Sekjennya Muhammad Yunan Nasution, mengeluarkan pernyataan politik membubarkan Masyumi, mulai dari pusat sampai ke daerah-daerah.

$$
\text { Pada masa Orde Baru, }
$$
Presiden Suharto tidak melirik kelompok Islam meskipun pada awalnya mereka digandeng untuk mengantarkan jalan kekuasaan. Pak Harto lebih tertarik menggandeng kelompok abangan-kejawen dan kalangan militer. Baru pada awal 1990-an, ia tertarik "melirik" Islam dengan menggaet kelompok kelas 
menengah teknokrat di bawah bendera ICMI (Ikatan Cendekiawan Muslim Indonesia) setelah terjadi friksi dengan sejumlah petinggi militer. Pak Harto dulu juga tidak memberi ruang gerak secuilpun untuk perkembangan "Islam politik" meskipun mendukung gerakan "Islam kultural" yang apolitis.

Pada Era-Revormasi, keran kebebasan berekspresi dan berserikat yang dulu ditutup rapat, kini pun dibuka kembali lebar-lebar. Indonesia menjadi bebas kemudian lahirlah partai partai berbasis keagamaan, yang mengakomondasi kekuatan politik identitas mereka. Adanya peluang itulah yang mendorong tumbuhnya partai-partai politik baru di era reformasi. Di era ini, pertumbuhan partai-partai politik ibarat jamur di musim hujan. Menyongsong Pemilu 1999 pemilu pertama era reformasi, 141 partai tercatat sebagai organisasi yang memiliki badan hukum partai politik dan tercatat di Departemen Kehakiman dan HAM.

Dari 141 partai politik tersebut, orientasi dan politik keagamaan yang menjadi basis pendirian partai sangat beragam. Ada yang didirikan atas dasar gender, seperti Partai Perhimpunan Indonesia; ada yang merupakan sempalan dari Golkar, seperti Partai MKGR; ada partai yang dibentuk atas identitas seperti Partai Tionghoa Indonesia (PARTI). ${ }^{4}$ Ada partai yang didirikan atas dasar orientasi politik masa lalu, seperti Partai Bulan Bintang (PBB) dengan mengusung kembali idiom-idiom Partai Masyumi yang telah lama "mati".

Di kalangan umat Islam misalnya, Deliar Noer (alm.) menghendaki didirikannya sebuah partai Islam sebagai penampung aspirasi umat. Didukung oleh beberapa aktivis Islam, mereka akhirnya mendirikan Partai Umat Islam (PUI). Kalangan Islam tradisionalis, yakni Nahdlatul Ulama (NU) akhirnya memelopori berdirinya Partai Kebangkitan Bangsa (PKB). PKB dapat disebut lahir dari rahim tokoh-tokoh NU, khususnya Abdurrahman Wahid. Demikian pula dengan lahirnya partai-partai agama lainnya, seperti

\footnotetext{
${ }^{4}$ Afan Gaffar, Politik Indonesia, Transisi Menuju Demokrasi, (Yogyakarta: Pustaka Pelajar, 1999), hlm. 316.
} 
Partai Damai Sejahtera (PDS), Partai Keadilan (PK)-Partai Keadilan Sejahtera (PKS), Partai Bulan Bintang (PBB), dan Partai Bintang Reformasi (PBR).

\section{B. Kekurangan dan Kelebihan dari Perkembangan Politik Agama}

Kekurangan dari Politik Agama adalah; Pertama berdasar hasil penelitian Fox dan Menchik menunjukkan sebagian dari posterposter dalam kampanye yang menonjolkan simbolisme identitas mempunyai karakter inklusif, misalnya dengan menampilkan secara bersamaan simbol-simbol yang merepresentasikan keragaman identitas di daerah. ${ }^{5}$ Namun dalam konteks yang berbeda, tidak jarang mobilisasi elektoral dilakukan dengan mengafirmasi kontestasi antarkelompok identitas hal tersebut rentan sekali menimbulkan konflik.

Kedua, mudah dijadikan alat politik Pragmatisme politik dan marjinalisasi kelompok masyarakat

${ }^{5}$ Colm Fox dan Jeremy Menchik, 2011.The Politics of Identity in Indonesia: Results from Campaign Advertisements, APSA 2011 Annual Meeting Paper. lokal telah mendorong menguatnya politik identitas. Simbol identitas (etnik dan agama) sering menjadi alat mobilisasi paling menonjol dalam pelaksanaan Pilkada. Hal ini nampak misalnya dalam riset Fox dan Menchik yang menunjukkan bahwa sebagian besar (65 persen) poster kampanye dalam Pilkada mengandung muatan yang menekankan pada dimensi identitas para kandidat dalam Pilkada.

Sedangkan hasil penelitian yang dilakukan Program Studi Agama dan Lintas Budaya atau Center for Religious and Crosscultural Studies (CRCS) menyebutkan bahwa permasalahan terkait kehidupan beragama terjadi akibat: pertama, sebagai negara demokrasi dengan mayoritas penduduk memegang teguh identitas keagamaan, kontestasi untuk mendorong peran agama di ruang publik adalah tidak terhindarkan. Namun ekspresi-ekspresi publik tentang agama dalam bentuk kekerasan dan pelanggaran terhadap prinsip kewargaan mestinya bisa dihindari atau dicegah. Penelitian CRCS menunjukkan sebagian besar 
aksi kekerasan dan persekusi terhadap kelompok agama tertentu adalah pengulangan dari aksi-aksi serupa sebelumnya, sebagian bahkan terjadi di tempat atau dengan kelompok sasaran yang sama, dan sejauh penelitian CRCS, tak pernah terjadi secara spontan. Hal ini menunjukkan bahwa sesungguhnya konflik-konflik semacam itu dapat dihindari; ini sekaligus juga menunjukkan lemahnya kapasitas pengelolaan keragaman dalam pengertian strategi pencegahan dan respons terhadap resiko konflik keagamaan.

Kedua, tingkat kemampuan masyarakat dan negara dalam mengelola keragaman beragam dari satu tempat ketempat lain. Di banyak tempat ditemukan komunitaskomunitas dengan penduduk yang berbeda identitas tetapi mampu hidup secara berdampingan (koeksisten) dalam kurun waktu yang lama. Namun sayangnya tidak cukup ada upaya untuk menjelaskan, mempublikasikan dan mentransfer kemampuan satu masyarakat dalam mengelola keragaman ke tempat lain sehingga potensi kekerasan di wilayah-wilayah yang rentan bisa diatasi. Sebaliknya, tidak sedikit situasi rukun di satu masyarakat dirusak oleh faktor-faktor eksternal termasuk informasi-informasi bernuansa konflik yang berasal dari tempat lain.

Ketiga, kapasitas masyarakat dan negara dalam mengelola keragaman seringkali diperlemah oleh kurangnya sinergi antarelemen. Perbedaan perspektif, pendekatan, dan kesalahpahaman seringkali menciptakan situasi saling menyalahkan antaraktor yang seharusnya bekerjasama dalam menciptakan kerukunan. Hal yang mengkhawatirkan adalah respons terhadap isu keragaman seringkali didasarkan pada opini, kecurigaan, atau kesalahpahaman daripada pengetahuan yang akurat berbasis riset. Akibatnya, tidak jarang potensi kekerasan bukan hanya tidak bisa dicegah, tetapi bahkan upaya menangani konflik keagamaan justru melanggengkan masalah. Kajiankajian yang dilakukan CRCS menggunakan konsep pengelolaan keragaman atau juga biasa kami sebut perspektif 'pluralisme 
kewargaan' yang melihat isu-isu dalam hubungan antar atau intraagama tidak terbatas pada masalah hukum dan perbedaan keagamaan, tetapi juga sebagai masalah ketatanegaraan dan sosial.

Berdasarkan hasil penelitian CRCS tersebut dapat dilihat bahwa politk agama juga memiliki kelebihan jika dikelola dengan baik. Perbedaan keagamaan semata bukanlah faktor penentu dalam konflik, begitu juga meski regulasi dan penegakan hukum dibutuhkan, pendekatan hukum perlu diperkuat oleh proses "rekayasa sosial" yang mendukung situasi koeksistensi atau kerukunan. Sehingga peran pemerintah sangat diperlukan untuk menciptakan kerukunan.

\section{Perkembangan Politik Aliran di Indonesia}

Dalam memahami politik aliran, konsep social cleavage yang ditawarkan Seymour M. Lipset dan Stein Rokkan membantu kita memahami bagaimana dasar pembentukan partai dipengaruhi oleh struktur sosial masyarakat. Struktur cleavage ini terbentuk berdasarkan perjalanan historis dengan menekankan terhadap konflik sosial yang fundamental. Lipset dan Rokkan (1967) menerjemahkan kerangka konflik ini dalam kaitannya dengan dua periode besar yang mengubah sosial masyarakat. Peristiwa pertama adalah revolusi nasional, dimana terjadi pertentangan antara pendukung kebudayaan yang tersentralisasi dan pendukung kebudayaan lokal. Periode ini juga ditandai dengan terbentuknya cleavage "agama-sekuler" dalam kerangka perlawanan yang sama terhadap kerangka dominasi gereja, terutama dalam bidang pendidikan. Peristiwa kedua adalah revolusi industri, yang memengaruhi pembentukan kerangka ekonomi primer (Urban) dan ekonomi sekunder (Rural). Pertentangan ini berlangsung antara kelas tuan tanah dan pengusaha yang membutuhkan lahan, satu untuk mempertahankan pertanian dan perkebunan, yang satunya membutuhkannya untuk mengembangkan industri.

Model pembacaan yang ditawarkan Lipset dan Rokkan yang melihat transformasi sistem politik 
aliran ini akan lebih jelas, apabila terlebih dahulu kita memperhatikan basis sosial mana dari masyarakat yang membentuk pilihan-pilihan tersebut. Disinilah kajian Clifford Geertz menemukan relevansinya dalam membantu pemahaman kita. Dalam konteks masyarakat Jawa, Geertz menunjukan terdapat polapola politik aliran dalam masyarakat, yang menjadi basis mobilisasi politik. Pengamatan Geertz dilakukan di Mojokuto Jawa Timur, tentang bagaimana kaitan antara profesi, dan penggolongan penduduk menurut pandangan masyarakat berdasarkan kepercayaan, preferensi etnis dan pandangan politik. Hasilnya adalah ada tiga inti struktur sosial masyarakat di Jawa yakni desa, pasar dan birokrasi pemerintah yang mencerminkan tiga tipe kebudayaan, santri, abangan, dan priyayi. $^{6}$ Struktur sosial desa "biasanya diasosiasikan kepada para

\footnotetext{
${ }^{6}$ Istilah Abangan, Santri, dan Priyayi bukan merupakan istilah yang diadaadakan oleh Clifford Geertz, tetapi diambil dari penggolongan yang diterapkan oleh masyarakat sendiri. Lihat dalam pendahuluan bukunya, The Religion of Java, terj. Aswab Mahasin: Abangan, Santri, Priyayi dalam Masyarakat Jawa, (Bandung: Dunia Pustaka Jaya, 1981), h. 8
}

petani, pengrajin dan buruh kecil yang penuh dengan tradisi animisme upacara selamatan, kepercayaan terhadap makhluk halus, tradisi pengobatan, dan sihir menunjuk kepada seluruh tradisi keagamaan abangan. Sementara pasar "terlepas dari penguasaan etnis Cina yang tidak menjadi pengamatan Geertz diasosiasikan kepada petani kaya dan pedagang besar dari kelompok Islam berdasarkan kondisi historis dan sosial di mana agama Timur Tengah berkembang melalui perdagangan dan kenyataan yang menguasai ekonomi Mojokuto adalah mereka memunculkan subvarian keagamaan santri. Yang terakhir adalah subvarian priyayi, varian ini menunjuk pada elemen Hinduisme lanjutan dari tradisi Keraton Hindu Jawa. Sebagaimana halnya Keraton (simbol pemerintahan birokratis), maka priyayi lebih menekankan pada kekuatan sopan santun yang halus, seni tinggi, dan mistisisme intuitif dan potensi sosialnya yang memenuhi kebutuhan kolonial Belanda untuk mengisi birokrasi pemerintahannya. 
Berbagai kajian yang mencoba menggunakan perspektif politik aliran bermunculan pasca karya monumental Geertz salah satunya adalah Herbert Feith yang berusaha menerjemahkan lebih lanjut konteks pembacaan Geertz dalam kerangka orientasi pilihan politik. Seperti Geertz, Feith (1966) menekankan perbedaan orientasi dasar, atau dalam istilah lain disebut "Weltanschauliche Grundlagen", yaitu perbedaan basis ideologi antara satu partai dengan partai lainnya. Basis ideologis itulah yang menentukan tujuan, program atau platform, komposisi kepribadian dalam politik. Perbedaan basis ideologis di dalam semua hal tersebut di atas akan menentukan jarak politik dari kekuatan politik yang ada.

Pemetaan aliran versi Feith terlihat lebih "canggih" dibandingkan dengan model trikotomi (abangan, santri dan Priyayi) dari Geertz karena tidak seperti Geertz yang hanya melihat tradisional-religio-politicalsystem,

Feith melihat adanya dua sumber utama pemikiran politik di Indonesia.
Pertama, bersumber dari tradisi (kebudayaan Hindu-Budha maupun Islam). Kedua, bersumber pada aliran pemikiran barat. Peluang bagi munculnya keragaman aliran politik dimungkinkan ketika muncul Maklumat Pemerintah yang ditandatangani oleh Wakil Presiden Mohammad Hatta, tanggal 3 November 1945, yang menyatakan bahwa "Pemerintah menyukai timbulnya partai-partai politik, karena dengan adanya partai-partai itulah dapat dipimpin ke jalan yang teratur segala aliran paham yang ada dalam masyarakat". Selanjutnya Feith menyatakan bahwa berawal dua sumber utama pemikiran politik di Indonesia inilah kemudian muncul lima aliran politik yaitu:

1. Komunisme yang mengambil konsepkonsep langsung maupun tidak langsung dari Barat, walaupun mereka seringkali menggunakan istilah politik dan mendapat dukungan kuat dari kalangan abangan tradisional. Komunisme mengambil bentuk utama sebagai kekuatan politik dalam Partai Komunis Indonesia. 
2. Sosialisme Demokrat yang juga mengambil inspirasi dari pemikiran barat. Aliran ini muncul dalam Partai Sosialis Indonesia.

3. Islam, yang terbagi menjadi dua varian; kelompok Islam Reformis (dalam bahasa Feith) atau Modernis dalam istilah yang digunakan secara umum yang berpusat pada Partai Masjumi; serta kelompok Islam konservatif atau sering disebut tradisionalis yang berpusat pada Nadhadul Ulama.

4. Nasionalisme Radikal, aliran yang muncul sebagai respon terhadap kolonialisme dan berpusat pada Partai Nasionalis Indonesia (PNI).

5. Tradisionalisme Jawa, penganut tradisi-tradisi Jawa. Pemunculan aliran ini agak kontroversial karena aliran ini tidak muncul sebagai kekuatan politik formal yang kongkret, melainkan sangat mempengaruhi cara pandang aktor-aktor politik dalam Partai Indonesia Raya (PIR), dan kelompok Teosufis (kebatinan)

Kelima aliran itu muncul dalam diagram pemikiran politik antara tahun 1945-1965 yang dibuat oleh Herbert Feith (lihat gambar).

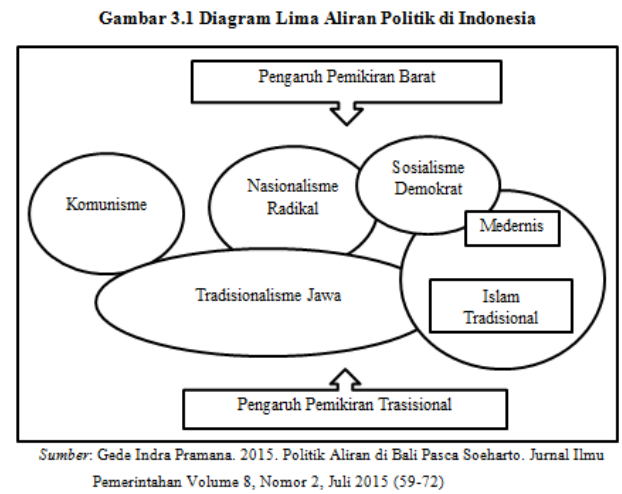

Seperti dinyatakan dalam diagram diatas, perspektif inilah yang menjadi kerangka umum pembacaan model politik aliran di Indonesia. Andreas Uffen (2008) lebih jauh menyediakan model pembacaan politik aliran dengan melihat hasil Pemilu 1999 dan Pemilu 2004. Uffen (2008) dalam Gede Indra (2015:62-63) menggunakan cleavage sosial ala Lipset dan Rokkan untuk membandingkan kiprah partai-partai pada Pemilu 1999 dan 2004, kemudian membandingkannya dengan hasil Pemilu 1955, Uffen sampai pada kesimpulan bahwa terdapat kontinuitas dalam aliran politik di Indonesia (lihat Tabel 1). 


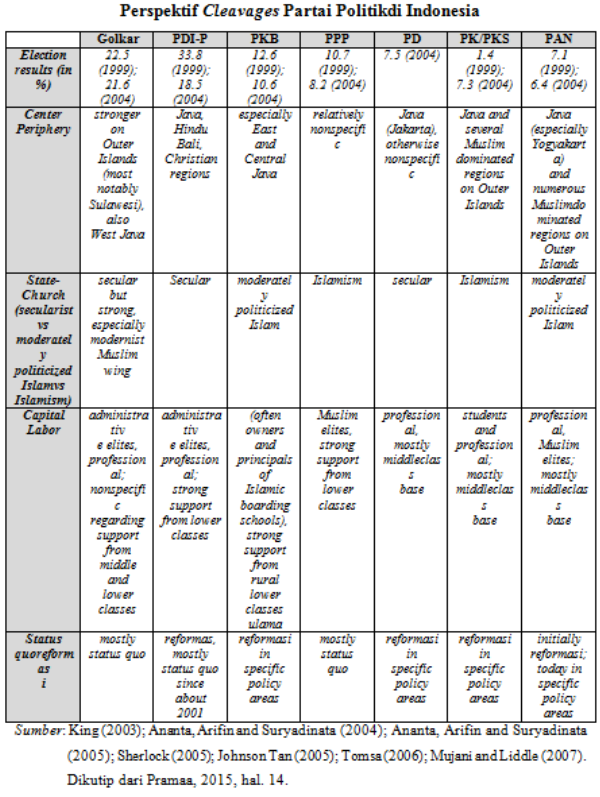

4. Bagaimana Seharusnya Bangsa Indonesia

Melihat

Perkembangan Politik Identitas, Berikan Solusi bagi Penyelengaraan Kehidupan

\section{Berbangsa}

Secara historis, pembentukan Indonesia sebagai bangsa baru terjadi tahun 1920-an, dilakukan melalui kegiatan intensif PI (Perhimpunan Indonesia) di Negeri Belanda, kemudian dikukuhkan oleh Sumpah Pemuda 1928. Semua peristiwa penting ini terjadi di zaman kolonial periode akhir. Selanjutnya dengan
Proklamasi 17 Agustus 1945, sebuah negara baru yang juga bernama Indonesia, muncul ke atas peta dunia, sekalipun Belanda dibantu Inggris sama sekali tidak rela dengan cetusan kemerdekaan rakyat terjajah ini. Seperti sudah disinggung di atas bahwa proklamasi kemerdekaan Indonesia bisa saja tertunda sekiranya PD II tidak meledak, sebab Belanda sebagai penjajah memang tidak pernah siap untuk melihat sebuah kemerdekaan bagi Nusantara yang sebagaian wilayahnya sudah cukup lama dikuasainya. Indonesia adalah negara kepulauan yang terluas di muka bumi. Jumlah pulaunya lebih dari 17.000, etnisitas, subkultur, dan bahasa lokalnya ratusan. Baswedan (2004)

Bahkan di Papua saja misalnya, tidak kurang dari 252 suku dengan bahasa khasnya masingmasing. Dari sisi keragaman budaya (pluralisme) ini saja, jika Indonesia bisa bertahan dalam tempo lama, maka menurut saya adalah mukjizat sejarah yang bernilai sangat tinggi. Oleh sebab itu, apa yang bernama politik identitas yang sering muncul ke permukaan sejarah modern Indo 
nesia harus ditangani dan dikawal secara bijak oleh nalar historis yang dipahami secara benar dan cerdas. Saat proklamasi, jumlah penduduk Indonesia adalah sekitar 70 juta; sekarang di awal abad ke-21 sudah menjadi sekitar 250 juta, mem bengkak lebih tiga kali lipat sejak 1945, telah muncul sebagai bangsa terbesar keempat di dunia sesudah Cina, India, dan Amerika Serikat.

Modal dasar untuk pengawalan keutuhan bangsa itu sudah kita miliki, yaitu, pengalaman sejarah berupa pergerakan nasional, PI, Sumpah Pemuda, Pancasila, dan adanya tekat bulat untuk mempertahankan dan membela keutuhan bangsa dan negara ini. Dalam ranah gerakan sosial keagamaan, ada Muhammadiyah dan NU, dua sayap besar umat Islam, yang telah mengukuhkan dirinya sebagai benteng demokrasi dan pluralisme di Indonesia. Sekalipun sering digerogoti oleh kelakuan politisi salah tingkah dalam berbagai perio de sejarah pasca proklamasi, toh sudah lebih enam dasawarsa, Indo nesia masih bertahan dengan segala keberuntungan dan mala petaka yang dialaminya.

Politik identitas serta solidaritas yang ada di Indonesia sekarang mengalami berbagai masalah. Hal ini terjadi karena adanya beberapa konflik antar suku, etnis, agama dan masalah-masalah lain yang sering terjadi di Indonesia. masalah kegalauan politik identitas ini terjadi karena banyak yang menganggap bahwa identitas hanya diartikan secara sempit yaitu identitas kelompok. Padahal pasca kemerdekaan bangsa Indonesia telah sepakat untuk menjunjung tinggi nilai identitas nasional yang bersumber dari nilai persatuan dan kesatuan dalam kebhinekaan. Artinya identitas antar suku, ras, agama dan antar golongan yang berbeda dijadikan sebagai alat pemersatu bangsa untuk mewujudkan nasionalisme Indonesia.

Semangat nasionalisme di Indonesia pada awalnya lahir dari bentuk perlawanan terhadap kolonialisme. Akan tetapi nasionalisme Indonesia juga di pengaruhi oleh adanya politik identitas serta solidaritas nasional. 
bagaimana suku-suku yang ada di Indonesia memiliki ciri khas sendirisendiri antara satu dengan yang lainnya, ini merupakan ciri dari nasionalisme yang ada di Indonesia. Sebagai contoh, Suku Jawa pada awalnya adalah sebuah suku yang terdiri atas komunal-komunal mempunyai norma yang sudah dijalankan dan di taati oleh masyarakat Suku Jawa. Artinya sebelum penjajah datang Suku Jawa sudah memiliki tatanan sosial masyarakat yang dijadikan landasan dalam kehidupan.

Tetapi adanya kolonialisme yang datang di Indonesia nilai tersebut menjadi luntur. Seperti yang telah disampaikan oleh George McTurnan kahin (2013:3). "Karakter perpolitikan masyarakat jawa yang sebelum masa penjajahan boleh dikatakan tidak terlalu otoriter menjelma sangat sewenang-wenang selama tiga abad pemerintahan kolonial". Pernyataan tersebut menunjukan bahwa akibat adanya kolonialisme maka politik identitas masyarakat jawa yang menjadi ciri khas masyarakat jawa menjadi luntur. Keinginan mengembalikan politik identitas yang telah lama sebagai aturan atau norma yang ada dimasyarakat tersebut yang akhirnya menjadikan sebagai simbol perlawanan kepada kolonialisme. Nasionalisme juga muncul dari adanya solidaritas yang tinggi yaitu rasa bahwa bangsa Indonesia tidak lebih rendah dari bangsa penjajah. Seperti keyakinan bahwa bangsa Indonesia memiliki peradaban besar yang pernah terjadi di nusantara. Seperti kerajaan Majapahit, Sriwijaya dan kerajaan-kerajaan yang lainnya telah membuktikan bahwa bangsa Indonesia dahulu mampu bersaing dengan bangsa asing.

Dalam situasi keterserakan identitas dan entitas-entitas perbedaan, politik perbedaan dan entitas-entitas perbedaan, politik perbedaan sangat subur dalam situasi negara atau masyarakat yang multikultural dan multietnis. Dalam kerangka ini, hubungan interaktif antar kelompok perbedaan, terutama kelompok etnis yang berbeda-beda harus menjalin suatu kerangka etis, dalam hal ini adalah sikap toleran. Toleransi politik hanya mungkin 
dalam suasana politik negara yang demokratis. Oleh karena toleransi politik (political tolerance) sangat dipengaruhi oleh sistem, struktur, dan atmosfer politik yang berlaku. John Sullivan dan kawan-kawan, yang menganalisis konsep dan penerapan toleransi poltik di tiga negara yang berbeda: Amerika Serikat,Selandia Baru, dan Israel, menemukan kadar intensitas toleransi yang berbeda-beda. Hal tersebut dipengaruhi oleh faktorfaktor antara lain tingkat kemakmuran ekonomi, struktur dan sistem politik, faktor psikologi politik.

Bangsa Indonesia harus melihat bahwa nasionalisme begitu penting bagi bangsa dan Negara Indonesia. karena semangat nasionalisme inilah yang akhirnya membawa bangsa Indonesia untuk keluar dari era kolonialisme dan imperialisme yang telah lebih dari tiga abad menjajah Indonesia. Semangat nasionalisme yang tinggi akhirnya melahirkan konsep persatuan dan kesatuan Indonesia. Bagaimana sebuah perbedaan mulai dari suku, ras, agama, dan antar golongan serta bahasa dijadikan sebagai alat pemersatu dan sebagai kekayaan keanekaragaman yang ada di Indonesia. Ketika berbicara tentang nasionalisme maka kita seharusnya tidak boleh melupakan adanya politik identitas yang ada di Indonesia. Misalnya di masyarakat Suku Dayak yang ada di Kalimantan, Suku Jawa atau suku-suku yang lainnya. Politik identitas yang ada disetiap suku ada bermacam corak dan latar belakang sendiri-sendiri, mulai dari kemunculan politik identitas yang di sebabkan oleh adanya ketidakadilan, wujud perlawanan, warisan nilai luhur, serta alat untuk menunjukan jati diri suku tertentu dengan suku lain.

Politik identitas yang ada di Indonesia yang begitu beragam tersebut harus diperhatikan oleh pemerintah Indonesia supaya adanya politik identitas kesukuan tersebut tidak mengganggu semangat nasionalisme. Akan tetapi adanya politik identitas tersebut bisa menguatkan nasionalisme yang ada di Indonesia dengan bentuk politik identitas nasional yang menjunjung tinggi nilai persatuan dan kesatuan 
dalam kebhinekaan. Kemudian sikap nasionalisme dan politik identitas harus dibarengi dingan sikap solidaritas kebangsaan yang kuat. Sikap solidaritas kebangsaan yang kuat akan melahirkan tatanan masyarakat yang stabil dan saling menghargai serta merasa memiliki individu satu dengan individu yang lainnya, dalam hal ini adalah warga negara. Akan tetapi pada dewasa ini tidak jarang solidaritas mengalami berbagai macam permasalahan, karena banyak masyarakat yang terjebak pada solidaritas dalam arti sempit yaitu kelompok. Banyaknya benturan antar suku, kelompok, agama bahkan suporter sepak bola menunjukan bahwa ada yang salah dalam memaknai sikap solidaritas dalam masyarakat. Seharusnya solidaritas dimaknai sebagai sikap yang saling menyayangi antar indivdu, sikap saling memegang teguh norma-norma yang ada di masyarakat, serta sikap saling merasa senasib dan secita-cita dalam bingkai Negara Kesatuan Republik Indonesia (NKRI). Dengan sikap solidaritas kebangsaan yang tinggi setiap warga negara maka akan menjadi sebuah gerakan bersama untuk mewujudkan negara yang adil dan makmur, sesuai dengan amanah Pancasila sebagai pandangan hidup bersama bangsa Indonesia.

Untuk mewujudkan nasionalisme dan politik identitas nasional Indonesia dibutuhkan solidaritas yang tinggi pada bangsa Indonesia. bangsa Indonesia tidak boleh terjebak pada solidaritas kelompok-kelompok yang melahirkan primordialisme dan chauvinisme. Kemudian kita akan terjebak pada fanatisme kedaerahan, kesukuan, agama, golongan, serta kelompokkelompok lainnya, yang pastinya akan melunturkan jiwa nasionalisme bangsa Indonesia. Konflik antar daerah, suku, agama, serta kelompok yang sekarang sering terjadi hanya akan memecah belah semangat persatuan dan kesatuan bangsa Indonesia.

\begin{tabular}{llr}
\multicolumn{2}{c}{ Ideologi } & melahirkan \\
nasionalisme & dan nasionalisme \\
melahirkan & identitas yang
\end{tabular}
selanjutnya disebut politik identitas. Ideologi merupakan sekumpulan ide atau gagasan yang berasal dari nilainilai budaya dan diterima oleh 
beberapa lapisan masyarakat sebagai pedoman menuju kearah perubahan yang di cita-citakan. Ideologi yang semula berarti gagasan, ide, cita-cita itu berkembang menjadi suatu paham mengenai seperangkat nilai atau pemikiran yang oleh seseorang atau sekelompok orang menjadi suatu pegangan hidup. Ideologi ibarat wadah atau konsep yang mewadahi beberapa kelompok masyarakat dengan berbagai macam identitas yang dimiliknya untuk dapat hidup dalam satu konsep tersebut. Wadah tersebut, apabila seluruh kelompok dapat menerima dan merasa terwadahi, akan manjadikannya sebuah identitas baru yang dianggapnya sebagai kekuatan untuk mencintai, memiliki kebanggaan dan memelihara kehormatannya yang kekuatan tersebut disebut sebagai Nasionalisme. Namun apabila wadah/identitas baru tersebut tidak dapat mewadahi identitas-identitas yang ada, akan timbul penonjolan oleh identitas-identitas tersebut untuk keluar dari wadahnya.

Penguatan identitas tersebut muncul apabila identitas yang dikonsepkan untuk mewadahiya dirasa tidak dapat mewakili atau menyatukan kelompok-kelompok tersebut. Bahkan, kekuatan kolompok tersebut menimbulkan juga ketegangan antar kelompok untuk memperoleh dominasi dari sebuah konsep yang akan dibangun. Penguatan identitas kelompok untuk menjadikannya sebagai dominasi dalam sebuah wadah atau bahkan keluar dari wadah disebut sebagai Politik Identitas. Tujuan sebenarnya dari politik adalah mencapai kebaikan bersama. Maka menurut saya bagaimana pun caranya, entah dengan menggunakan politik identitas atau identitas politik, asalkan pemerintahan yang dibangun atas dasar politik tersebut mampu mewujudkan kebaikan bersama maka ia menjadi baik.

\section{REFRENSI:}

Abdilah S, Ubed. 2002. Politik Identitas Etnis: Pergulatan Tanda Tanpa Identitas. Magelang: Yayasan Indonesiatera.

Baswedan, A. (2004). Political Islam in Indonesia. Asian Survey Vol. 5, hal. 669-690. 
Beyme, Klaus Von. 1996. Federalism, Democracy, And The Politics Of Identity. University of Heidelberg.

Fox, Colm dan Menchik, Jeremy. 2011. The Politics of Identity in Indonesia: Results from Campaign Advertisements, APSA 2011 Annual Meeting Paper.

Gaffar, Afan. 1999. Politik Indonesia, Transisi Menuju Demokrasi. Yogyakarta: Pustaka Pelajar.

Hefner, Robert W. 2007. Politik Multikulturalisme:

Menggugat Realitas

Kebangsaan. Yogyakarta: Impulse.

Heller, Agnes dan Punsher, Sonja. 1995. Biopolitical Ideologies an their Impact on the New Social Movements. A New Handbook of Political Societies. Oxford, Blackwell.

James G. Kellas, 1988, The Politics of Nationalism and Ethnicity, edisi II, New York: ST Martin's Press.

Lipset S M \& Rokkan S. 1967. Cleavage structures, party systems, and voter alignments: an introduction. New York: Free Press. p. 164.

Mahasin, Aswab. 1981. Abangan, Santri, Priyayi dalam Masyarakat Jawa. Bandung: Dunia Pustaka Jaya.

Sumanto, Al Qurtuby. 2016. Agama, Politik, dan Politik Agama. http://www.dw.com. diakses pada 11 Maret 2016.

Pramana, Gede Indra. 2015. Politik Aliran di Bali Pasca Soeharto. Jurnal Ilmu
Pemerintahan Volume 8, Nomor 2, Juli 2015.

Widayanti, Titik. 2009. Politik Subalter: Pergulatan Identitas Waria. Yogyakarta: UGM. 